\title{
COMMUNICATION TECHNOLOGIES OF CROWDSOURCING IN CONTEMPORARY GLOBAL AND RUSSIAN PUBLIC POLICY ${ }^{1}$
}

\author{
Liliya S. Pankratova \\ Saint Petersburg State University, Saint Petersburg, Russian Federation \\ Svetlana V. Shakarbieva \\ Volgograd State Socio-Pedagogical University, Volgograd, Russian Federation
}

\begin{abstract}
Introduction. The paper studies crowdsourcing technologies of public communication that is an essential part of the global and regional contemporary political spaces as a method of nonviolent conflict resolution and reduction of social tensions in different parts of the world. Methods. The authors examine crowdsourcing technology of public political communication based on classical and modern concepts of political-communicative interaction of society and government (J. Habermas, M. Castells, G. Tarde, J. Shurovyeski, J. Howe). The paper reveals the specifics of implementation of crowdsourcing in the international public policy on the example of the United Nations Organization world agenda setting e-discussion projects, and in the political context of modern Russia with the spread of e-government practices, e-participation of individuals and groups. Results. The introduction of crowdsourcing is one of the important stages in the process of increasing the effectiveness of communication between government bodies, local authorities, business, political and public associations in developing and making the most important decisions for citizens all over the world. The demand for crowdsourcing in both international and Russian public policy is connected, on the one hand, with the recognition that a huge number of citizens have the abilities, talent, necessary competencies and qualities of innovative activity, and, on the other hand, with significance of development of 'human capital', understood as a set of knowledge and skills used to meet the diverse needs of citizens and society as a whole, for the modern competitive and challenging world. Discussion. The limits of crowdsourcing technology in public policy need to be evaluated from the perspective of social and cultural stratification and inequality, potential of mediated collective action.

L.S. Pankratova has carried out complex analysis of the concept of public sphere in the context of new information communication technologies dissemination and examined the cases of crowdsourcing projects introduced by the United Nations Organization over recent years, as well as made professional translation of the article. S.V. Shakarbieva has conducted interdisciplinary analysis of social theories to interpret the concept of crowdsourcing and investigated the perspectives and limits of the spread of crowdsourcing communication technologies in the modern public policy space of Russia.
\end{abstract}

Key words: crowdsourcing, public policy, communication technology, the United Nations Organization, Russia, e-discussion, e-governance, e-participation.

Citation. Pankratova L.S., Shakarbieva S.V. Communication Technologies of Crowdsourcing in Contemporary Global and Russian Public Policy. Vestnik Volgogradskogo gosudarstvennogo universiteta. Seriya 4, Istoriya. Regionovedenie. Mezhdunarodnye otnosheniya [Science Journal of Volgograd State University. History. Area Studies. International Relations], 2018, vol. 23, no. 6, pp. 208-216. DOI: https://doi.org/10.15688/jvolsu4.2018.6.17

\section{КОММУНИКАТИВНЫЕ ТЕХНОЛОГИИ КРАУДСОРСИНГА
В СОВРЕМЕННОЙ ГЛОБАЛЬНОЙ И РОССИЙСКОЙ ПУБЛИЧНОЙ ПОЛИТИКЕ 1}

\author{
Лилия Сергеевна Панкратова
}

Санкт-Петербургский государственный университет, г. Санкт-Петербург, Российская Федерация 


\section{Светлана Владиславовна Шакарбиева}

Волгоградский государственный социально-педагогический университет, г. Волгоград, Российская Федерация

Аннотация. Введение. Статья посвящена рассмотрению краудсорсинговых технологий публичной коммуникации в глобальном и региональном современных политических пространствах как средств мирного, ненасильственного разрешения конфликтов и снижения социальной напряженности в различных частях мира.

Memodbl. Авторы концептуализируют краудсорсинговую технологию публичной политической коммуникации на основе классических и современных теорий политико-коммуникативного взаимодействия общества и власти (Ю. Хабермас, М. Кастельс, Г. Тард, Дж. Шуровьески, Дж. Хау и др.). Раскрыта специфика внедрения краудсорсинговых технологий в международной публичной политике на примере организации электронных дискуссий по формированию глобальной повестки дня Организацией Объединенных Наций, а также в политическом пространстве современной России в связи с распространением практик электронного управления, электронного участия индивидов и групп.

Результаты. Акцентируется внимание на том факте, что внедрение краудсорсинга выступает одним из важных этапов в процессе повышения эффективности коммуникации между органами государственной власти, местного самоуправления, политическими и общественными объединениями, бизнесом при выработке и принятии наиболее значимых для граждан решений. Востребованность краудсорсинга в международной и российской публичной политике связана, с одной стороны, с признанием того, что огромное количество граждан обладает способностями, талантом, необходимыми компетенциями и качествами инновационной активности, а с другой стороны, со значимостью развития «человеческого капитала», понимаемого как совокупность знаний, умений, навыков, использующихся для удовлетворения многообразных потребностей граждан и социума в целом, в современных конкурентных и сложных мировых условиях.

Обсуждение. Открытым и малоизученным остается вопрос об ограничениях использования краудсорсинговой технологии для реализации успешной публичной политики в контексте существующей социальной и культурной стратификации и неравенства, потенциала опосредованного коллективного действия.

Л.С. Панкратова провела анализ современных подходов к изучению публичной сферы в контексте распространения современных информационно-коммуникативных технологий, рассмотрела кейсы международных краудсорсинговых проектов, реализованных $\mathrm{OOH}$ в последние годы, а также осуществила профессиональных перевод статьи на английский язык.

С.В. Шакарбиева рассмотрела и проинтерпретировала краудсорсинг с позиций различных социальных теорий, а также выделила ресурсы, перспективы и ограничения использования и распространения данной технологии в современном пространстве публичной политики РФ.

Ключевые слова: краудсорсинг, публичная политика, коммуникативные технологии, ООН, Россия, электронная дискуссия, электронное правительство, электронное участие.

Цитирование. Панкратова Л. С., Шакарбиева С. В. Коммуникативные технологии краудсорсинга в современной глобальной и российской публичной политике // Вестник Волгоградского государственного университета. Серия 4, История. Регионоведение. Международные отношения. - 2018. - Т. 23, № 6. - С. 208216. - (На англ.). - DOI: https://doi.org/10.15688/jvolsu4.2018.6.17

Introduction. Over the first decades of the $21^{\text {st }}$ century, the necessity of political project management that intensely adopts technologies and methods recently applied only in business and social spheres has become more obvious. This is due to the increased scientific component in formulating and solving problems to improve communication between global and/or local government and society. At the same time, the authors share the basic assumption that the process of informatization of society stands as one of the most important sources of reproduction of modern democratic values and mechanisms. In this regard, the study of project communication technologies, such as crowdsourcing, is theoretically and practically important and indemand.

International and Russian political practice of information and communication technologies development shows that there is increasing number of hardly predictable effects in all areas of social life. The public policy actors that are more and more integrated with the Internet environment are formed: network political parties and civil movements, open electronic governments, as well as forms of network public administration, etc. Hence, there is a need for regular and sciencebased monitoring of the current situation, as well 
as forecast of alternative scenarios related to communication mobilization of various institutional and non-institutional subjects of the political process at the global, regional and local levels. The use of crowdsourcing technologies in the political sphere has become a reality and its country, sociodemographic, and other specificities should be analyzed.

Methods. The research methodology of the paper includes the complex and interdisciplinary analysis of political, communication and sociological theories to examine the use of crowdsourcing technologies of political communication in the context of electronic global and regional governance and participation expansion. Analysis of the cases of implementation of crowdsourcing in the practice of public policy of the United Nations Organization is conducted. The regional context of Russia for the spread of crowdsourcing in political process is scrutinized.

We consider public policy in the framework of Jurgen Habermas's concept of the public sphere, which presents an ideally-typical model of interaction between various actors of political process. The public sphere is defined as a space of civic and political activity [6] with communicative actions (exchange of opinions, discussion of social and economic issues) between representatives of any social group. It could be done through both personal interactions (meetings, Internet forums) and media publications and discussions. Private problems of citizens become political when they get into the sphere of public discussion. Habermas notes that communicative actions succeed under the following conditions: decentralization of social ties; equality of participants in discussion; openness of dialogue; orientation towards mutual understanding; rational and critical nature of the dialogue; clarity of arguments and reliability of information. Public policy presupposes the existence of a space that is autonomous from state and any other control for information and communication activities - civic participation by all actors of the political field in order to work out adequate solutions to social and political problems on the basis of discussion and consensus.

Manuel Castells considered the Internet as one of the key arenas for public and political interactions and discussions at the contemporary stage of the societal development. "Cyberspace has become a global electronic agora where the diversity of human disaffection explodes in a cacophony of accents" [2, p. 138]. The importance of the Internet as a communicative space for politics is enormous. Here discursive struggles and competition for constructing ideas about society, governance, economy and culture take place between various social and political actors (citizens, social movements, opinion leaders, business, politicians, etc.). Communication on the Internet allows users to participate in political dialogue with diverse in social and demographic sense participants that, in accordance with their interests and goals, can create and reconfigure their communication networks. According to Castells, communication in the Internet is a 'mass self-communication'. While preserving the mass form of communication (the transfer of a message from many to many), the communication process in the Internet turns out to be autonomous (independent selection of a recipient and sources of information). The dialogue in the network is based on horizontal ties, characterized by interactivity, multimodality and hypertextuality, variety of the used materials (video, audio, photos, texts) [1, p. 6-7].

Due to modern information and other technologies it became possible to "distinguish among a large stock of general ideas, mainly between real science and comparative talk," and in fact "real sciences" related to the study of the characteristics of mass communication and proving that Gabriel Tarde rightly understood differences in the interpretation of the so-called crowd and the public. "The crowd is a social group of the past; after the family, it is the oldest of all social groups. It is in all of its forms - whether sitting, motionless or moving - is not able to expand beyond a certain limit; when its leaders no longer keep it in manu, when it ceases to hear their voice, it splits" [13, p. 5]. "...But the public is endlessly extensible, and along with this stretching its social life becomes more intense, you cannot deny that it will be a social group of the future. Thus, due to the combination of three mutually supporting inventions: book printing, railways, and telegraph the press acquired its frightening power, this wonderful phone that has immensely expanded the ancient audience of tribunes and preachers. So, I cannot agree with courageous writer, Dr. Le 
Bon, stating that our age is "the era of the crowd". Our age is the era of the public or the publics that is not similar to his claim" [13, p. 6]. Tarde's reflections on the crowd, the public and the methods of converting the first into the second anticipated the Internet. Today they can be called prophetic in terms of the birth of crowdsourcing technologies, because at the heart of this "transformation" is the spontaneous formation of individuals who have the potential to be enlightened independently of somebody and something. For example, a necessary and sufficient condition to be heard are only ordinary skills to use modern technologies available to everyone.

In this context it is interesting to refer to the study of the 'wise crowd' by James Surowiecki, who identified four conditions characterizing it: diversity of opinions (each person should have his/ her own opinion, even if it is the most incredible interpretation of the known facts); independence of the participants (the opinion of some members of the group is not dependent on the judgment of others); decentralization (the citizens have the opportunity to base their opinion on local info); aggregation (the mechanism of combination of personal opinions into collective decision). Surowiecki believes that "... if a group satisfies those conditions, its judgment is likely to be accurate" $[12$, p. 10]. However, four conditions, that according to Surowiecki characterize "wise crowd', may not always be presented. So, there is a high probability that the group judgment may be wrong. The author believes that to demonstrate the collective wisdom, a group must share at least some reliable data in the 'information' part of the 'information minus error' equation. The wisdom of the group is not surprising for him: “...we are the products of evolution, and presumably we have been equipped to make sense of the world around us" [12, p. 11].

Government institutions largely reproduce the mechanism, revealing a certain way for citizens to get more opportunities to realize their needs. Moreover, Surowiecki draws attention to another important conclusion: "With most things, the average is mediocrity. With decision making, it's often excellence. You could say it's as if we've been programmed to be collectively smart" $[12$, p. 11]. Communication field of each individual interacts with the communication fields of group members, creating certain tension for the development of meanings of this communication and transition to a new level of interaction. To participate in the political process for large public groups simultaneously it is necessary to understand that the state for them is a world in which they exist; how much these groups are aware of their country's history, its current needs, and future strategies. Surowiecki has an idea that "truly successful decision making, of course, demands more than just a picture of the world as it is. In addition, it demands a picture of the world as it will (or at least as it may) be" [12, p. 11].

Thus, the "picture of the world", for the sporadically educated, but in general the 'wise' in decision-making crowd, it is a kind of "mosaic" formed from the parts of awareness of many people. Parts of this 'mosaic' are fields of communication connected by "communication threads". Change of the "picture of the world' is a consequence of the political processes that are now becoming an integral part of a network entity of public political communication. This way the need of crowdsourcing technologies is objectified.

The most popular definition of the term 'crowdsourcing' is the following: bringing wide range of people in to the solution of certain problems of innovative production in order to use their creative abilities [7, p. 5]. In June 2006, the editor of Wired magazine Jeff Howe published an article entitled The Rise of Crowdsourcing, where the author for the first time used this concept, which is gradually spreading throughout the world. This term, according to E.I. Ryabtseva, represents a business model based on attracting the 'crowd' (meaning volunteers) to production and distribution of goods and services, as well as suggestion of their ideas or solutions to certain problems. These volunteers are often at the same time consumers of these goods or services. Crowdsourcing allows you to reduce costs, forcing expensive outsourcing services out [11]. Thus, the company sends the specific production function not to any certain persons on the basis of a public offer without an employment contract. Crowdsourcing is a complex of integrated methods representing various spheres of social activity. Intrinsically that is a modern communication technology, as technology is a set of methods and tools to achieve the desired result [10]; in the 
broadest sense - the application of scientific knowledge to solve practical problems.

Analysis. Political technologies are defined as one of the areas of political activity, which develops methods of contacting with politicians, the public, social movements, NGOs and any other members of society, their special position in the system of communication and interaction between the global and state government and society should be recognized. Despite the fact that the manipulation of public opinion still has the leading position in crowdsourcing interaction, this type of political communication is seriously transformed along with the changes of social and political institutions due to the involvement of a progressive number of citizens in the new realm of communication - Internet communication. But such contacts are not only within the virtual space. Even those members of society that are not users of World Wide Web, because of age or other reasons, often receive information from Internet users. Thus, the virtual and real processes collide (maybe not that often yet) and generate a variety of opinions, which in turn continue to exist depending on different communication factors. The latter include, for example, the power of emotional information influence on the recipient, or convincing facts that shatter the usual way of thinking of those who receive information, or simply usual reaction to rumors, etc. However, the fundamental role here is played by Internet communication, because of the number of agents capable to be simultaneously in a single field of interaction due to the same reason.

Undoubtedly, crowdsourcing political technologies, working with large target groups, often considered as the field of political relations with the public mainly associated with production and implementation of information, techniques and methods of manipulation of public opinion. Contemporary crowdsourcing, unlike the usual PR, seeks to improve the efficiency of politicians, political groups (parties and associations) and organizations activity. It is the struggle for power in the state or in the global arena in situation when it is impossible to hide anything or openly manipulate the public. The principle of crowdsourcing is project like, meaning to attract a large number of agents of communication it is necessary to identify the target group and investigate its needs, set goals, and develop an action plan to use its intellectual resources.
Thus, to consider Russian specifics of crowdsourcing technologies usage, it is necessary to take into account existing political regime in the country. The most common today in Russia is business crowdsourcing. Business is more often faced with challenges where it is preferably to have several solutions in order to choose the optimal one. Examples of crowdsourcing in business are very diverse: the development of a slogan for the campaign, the development of design for a cover for a music album, and others [3]. It is important to understand that solutions for business goals fit into the concept of "corporate policy", which in turn should be consistent with the relevant law that supports the state. Therefore, the interests of society realized in the field of business are always directly or indirectly connected with the objectives of the political power in the perspective of macro and micro political economy, as well as socio-political strategies.

Based on the fact that the policy is related to the issues and events of public life that reflect the functioning of the Russian state, the concept of 'social and public crowdsourcing' should be mentioned. This kind of crowdsourcing is based on the solution of any problems connected with public interest and social life of people. It includes scientific tasks, as well as search for missing people, the construction of a kindergarten or other object by joint efforts, or the various charitable projects. Thus, the use of crowdsourcing technologies in the process of democratization of the Russian society and the state is at the initial stages of communicative development. Commonly the concept of political crowdsourcing describes projects that try to find out the opinions about different actions of the state. Usually this kind of crowdsourcing is carried out in the mode of voting with the use of Internet technologies.

The most realistic and promising fields of application of political crowdsourcing in Russia are the following: creating an innovative political product; finding the best solutions in any socio-political issue; collecting and processing the necessary information; exploring public views about political activities or products, etc. In the process of expansion of cooperation between the society and the government a question about the definition of crowdsourcing in the socio-political space is arising, within which forms the mechanism of accelerated "transformation of 
the crowd into the audience". Taking into account the views of opponents of the use of crowdsourcing to solve any problems, because they consider that the crowd is not able to work out important issues, the question of creating a special space becomes extremely significant. From our point of view, the crowdsourcing space describes the integration of virtual and real spaces, where the boundaries (physical or cultural) cease to be important at the time of working on a specific task. In this space crowdsourcing has the following functions: informational; educational; competence formation and others.

The good successful examples of crowdsourcing technology application for various global and local challenging tasks are demonstrated in recent years by some of the United Nations Organization's structures and institutions, for example: GeoTag-X crowdsourcing research project aimed at working out solutions to cope with damages made by ecological or other sorts of disasters, initiated by the United Nations Institute for Training (UNOSAT) and partners [5]; renewable energy challenge for individuals and companies to find the best way to help returnee families in rural Bosnia and Herzegovina conducted by United Nations Development Programme (UNDP Eurasia) in cooperation with NGOs [4]; the United Nations online volunteering service (UNV) platform that enables to connect local and international organizations, individuals, authorities and the UN agencies via the Internet for realization of different projects and initiatives (research, outreach and advocacy, etc.) [15]. Many of the UN's crowdsourcing projects proved to be efficient in ability to introduce the intellectual and creativity potential of citizens and organizations of different countries to innovative activities and problem solutions through sharing and discussion of their ideas.

Out of the previous crowdsourcing experience the idea to organize and support a worldwide dialogue on the world agenda setting that would implement the idea of Habermas about public space for political and social discussion between global and local government, civil society and other stakeholders (business) led to the creation by the UN Secretary-General with the UNDP the initiative named United Nations Sustainable Development Goals (SDG) Action
Campaign. It is the Internet based platform for a worldwide survey on the goals that should be attained by 2030 according to the Global Goals signed by the leaders of 193 countries at the UN meeting in 2015. The task of the crowdsourcing campaign is to aware people around the globe about the aims of sustainable development, to support them contribute to their fulfillment through media, educational collaborative activities and ediscussion (The world we want 2030 platform [14]), to find out and analyze regional, age, gender view peculiarities on global goals agenda and main problems of everyday life.

The participants of the global survey asked to vote for the main problems they face with in order for the UN organizers to be able to prioritize the issues and tasks for various social groups and regions as the ones for urgent actions and crowdsourcing solutions. It is up to six issues (which coincide with the global goals) respondents may vote online: ecological (life below water; clean water and sanitation; climate action; affordable and clean energy; life on land), vital (zero hunger; good health and well-being), social (peace, justice and strong institutions; quality education; no poverty; sustainable cities and communities; partnerships for the goals; decent work and economic growth; gender equality; reduced inequalities), socio-economic (industry, innovation and infrastructure; responsible consumption and production). Following the choice of issues that concern respondents, voters are inquired to assess the progress in the situation in the last 12 months. There are five options on a scale for each issue from 'got worse' to 'got better'. While keeping the voting process anonymous, as much as it seems possible considering the privacy, transparency and technology risks in the Internet, the required socio-demographic information about a voter includes gender, age, education level, geographical location, disability for big data analysis. At the end the contact information (email address obligatory, mobile number optional) of a respondent is required for further citizens' network cooperation. The questionnaire part of the survey could be filled up with photo materials supplied by voters that showcase the pointed and discussed problems in the frame of Humans of MY World (HOMY) photo-narrative project [9].

The results of the global survey are constantly updated that allows flexibly and up-to- 
date monitor situation and collect evidences. Up till now the total number reached 372452 votes and it continues growing. The previous prototype crowdsourcing survey initiative My world 2015 ended in 9736484 votes [8]. It is important to mention that the dominant age group of respondents was from the youngers (16-30 years old) $-80,8 \%$ for the last survey, $54 \%$ for the My world 2015 survey; the minor age group represented is elder people (61 and above) $0,9 \%$ and $2 \%$ in accordance. For others the results are the following: 15 or younger $-5,1 \%$ and $23 \% ; 31-45$ years old $-10,7 \%$ and $15 \%$; 46-60 years old $-2,6 \%$ and $5 \%$ in accordance. Both male and female voters are almost equally represented in both surveys, the last one also includes the options 'other gender' and 'not specified' [8;9].

Among the respondents of My world 2030 survey more than two thirds answered that they do not know about the United Nations the Sustainable Development Goals. The top ten priority global goals among the declared by the UN seventeen ones according to voting are: decent work and economic growth; good health and well-being for people; gender equality; quality education; reduced inequalities; clean water and sanitation; no poverty; peace, justice and strong institutions; climate action; industry, innovation and infrastructure. Each of these issues scored in October 2018 more than 120000 votes. At the moment, the more actively taking part in the survey are the self-reported citizens of Mexico (>217 000 respondents), Colombia ( $>64000)$, Mali (>33000), Morocco (>17 000), Germany $(>2600)$, Sweden $(>2200)$, India $(>2100)$, France $(>1000)$, the USA $(>900)$, Russia $(>500)$, etc. [9].

To understand the emerging results of agenda setting process through crowdsourcing with survey forms it is significant to learn about the peculiarities of information dissemination about the project. It will help to interpret the imbalances in the proportion of answers among different groups of voters (by age, by country and others). Another aspect that should be kept in mind while interpreting the data is accessibility (technology, knowledge, skills) of the web platform to various citizens (migrants, refugees, elder people, etc.). Despite the mentioned imperfections of the communication technology the organizers consider it as one of a few instruments that really may promote and realize global public discussion on the future development of the world, active people's engagement through creative and innovative communications.

Results. The study of the content, the functional and operational characteristics of crowdsourcing communication technologies and models confirms the thesis of a deep and comprehensive communicative interdependence of autonomous states, nations and the world community as a whole. Safe development of societies and sustainable development of the world, the stability of political systems functioning is directly related to the practices of e-governance and e-participation. The boundaries between the concepts of 'internal communication' and 'external communication' blurred with unpredictable speed.

Thanks to crowdsourcing, new technologies have increased the transparency and openness of the decision-making process, significantly optimized information exchange, opened new opportunities for state / global citizens' engagement in the political process, and expanded opportunities for democratic participation. Hence, crowdsourcing is able not only to attract those wishing to actively participate in political processes, but also creates (spatial) conditions for the involvement of educated, intelligent, modernminded citizens in the decision of the world, regional, state, and local problems by means of social, political or business activity. Crowdsourcing quickly becomes a communication political technology, as the network space literally forces government, society, and business to interact with each other. Most likely, its popularity is due to the initially incorporated in it mechanism of recognition of professionalism, talent, or abilities of a huge number of active citizens. It is connected with an issue of 'human capital' that is understood as a set of knowledge and skills that are used to meet the diverse needs of citizens and society.

Thus, political and social sciences have the task to verify the rationality and efficiency of the simultaneous presence of a huge number of agents of information and communication process of specific social solutions, economic, political and legal problems, suggest ways to minimize possible risks and threats. The phenomenon of trust in the political and social information received both by individuals and their groups is of special significance. Trust is based on the ability of expert 
communicator (in this case in the framework of multi-vector electronic control and participation process) - ability to accurately formulate the problem, impression of the veracity of the transmitted information, and the competence of the informant. In this study the possibility and efficiency of crowdsourcing technologies in the context of expansion in the United Nations Organization and Russia of e-democracy, egovernment, and e-practices are equally demanded by the state and civil society in sense of development of global and state public policy.

The development of crowdsourcing technologies and communication models in the United Nations' projects, as well as in Russia, is creating new opportunities for the realization of the principles of the 'digital democracy', implying the expansion of opportunities for participation of network civil society in the implementation of public policy and management decisions.

\section{NOTE}

${ }^{1}$ The parts Methods (the complex analysis of the concept of public sphere in the context of new information communication technologies dissemination), Analysis (the examination of the cases of the United Nations Organization's projects implementing crowdsourcing communication technologies in global public policy) and Results have been prepared by L. Pankratova under the project No. 16-18-10315 "Normative Frameworks, Policy and Structural Transformation of the United Nations: International Institution in a Tangle of Megatrends of the $21^{\text {st }}$ century" funded by Russian Science Foundation at Saint Petersburg State University).

The parts Introduction, Methods (the interpretation of the crowdsourcing political technology from interdisciplinary perspective of social theories) and Analysis (the examination of the perspectives and limits of the spread of crowdsourcing communication technologies in the modern public policy space of Russia) have been prepared by S. Shakarbieva under the project No. 17-13-34039 "Strategies, innovative technologies of institutionalization and functioning of public policy in the Volgograd region" funded by the RFBR and Administration of the Volgograd region.

\section{REFERENCES}

1. Castells M. Networks of outrage and hope: social movements in the Internet age. Cambridge, Polity Press, 2015. 328 p.

2. Castells M. The Internet galaxy: reflections on the Internet, business, and society. Oxford, Oxford University Press, 2001. $292 \mathrm{p}$.

3. Chto takoe kraudsorsing [What is Crowdsourcing]. URL: http://dengodel.com/ interesting/145-chto-takoe-kraudsorsing.html (accessed 7 October 2018).

4. Energy challenge to provide power for war returnees in Bosnia and Herzegovina. URL: http:// www.undp.org/content/undp/en/home/presscenter/ articles/2012/11/30/undp-launches-energy-challengefor-war-returnees-in-bosnia-and-herzegovina.html (accessed 8 October 2018).

5. GeoTag-X. URL: http://geotagx.org/ (accessed 8 October 2018).

6. Habermas J. The structural transformation of the public sphere: an inquiry into a category of bourgeois society. Cambridge, Massachusetts, The MIT Press, 1991. $301 \mathrm{p}$.

7. Howe J. Crowdsourcing: how the power of the crowd is driving the future of busines. Random House Business, 2008. 312 p.

8. My world 2015. Analytics. URL: http:// data.myworld2015.org/ (accessed 8 October 2018).

9. My world 2030. The United Nations global survey for a better world. URL: http:// about.myworld2030.org/humans-of-my-world/ (accessed 8 October 2018).

10. Nekrasov S.I., Nekrasova N.A. Filosofiya nauki i tekhniki: tematicheskii slovar [Philosophy of Science and Technology: Thesaurus]. Orel, OGU Publ., 2010. 289 p.

11. Ryabtseva E.I. Kraudsorsing ili Perevod "tolpoy" [Crowdsourcing or Translation by "Crowd"]. TranslationDirectory.com. Portal for language professionals and their clients. URL: http:// www.translationdirectory.com/articles/article1267.htm (accessed 7 October 2018).

12. Surowiecki J. The wisdom of crowds. New York, Anchor books, 2005. $336 \mathrm{p}$.

13. Tarde G. Obshchestvennoe mnenie i tolpa [Public Opinion and the Crowd]. Moscow, Institut psikhologii RAN; KSP+ Publ., 1999. 120 p.

14. The world we want. URL: http://www. worldwewant2030.org/ (accessed 8 October 2018).

15. UN Volunteers. URL: https://www. onlinevolunteering.org/en (accessed 8 October 2018). 


\section{ПОЛИТИЧЕСКИЕ НАУКИ И РЕГИОНОВЕДЕНИЕ}

\section{Information about the Authors}

Liliya S. Pankratova, Candidate of Sciences (Sociology), Senior Lecturer, Department of Sociology of Culture and Communication, Saint Petersburg State University, Universitetskaya Emb., 7/9, 199034 Saint Petersburg, Russian Federation, 1.s.pankratova@spbu.ru, https://orcid.org/0000-0002-7658-1409

Svetlana V. Shakarbieva, Candidate of Sciences (Philosophy), Associate Professor of Department of Social Work, Volgograd State Socio-Pedagogical University, Prosp. Lenina, 27, 400066 Volgograd, Russian Federation, svch1963@yandex.ru, https://orcid.org/0000-0002-9980-015X

\section{Информация об авторах}

Лилия Сергеевна Панкратова, кандидат социологических наук, старший преподаватель кафедры социологии культуры и коммуникации, Санкт-Петербургский государственный университет, Университетская наб., 7/9, 199034 г. Санкт-Петербург, Российская Федерация 1.s.pankratova@spbu.ru, https://orcid.org/0000-0002-7658-1409

Светлана Владиславовна Шакарбиева, кандидат философских наук, доцент кафедры социальной работы, Волгоградский государственный социально-педагогический университет, просп. им. В.И. Ленина, 27, 400066 г. Волгоград, Российская Федерация, svch1963@yandex.ru, https://orcid.org/0000-0002-9980-015X 